УДК 553.98(479.24):550.8.072

\title{
ПЕРСПЕКТИВЫ НЕФТЕГАЗОНОСНОСТИ ШАМАХЫ-ГОБУСТАНСКОЙ ВПАДИНЫ В СВЯЗИ С ЕЁ СТРУКТУРНО-ТЕКТОНИЧЕСКИМИ ОСОБЕННОСТЯМИ
}

\author{
Насибова Гюльтар Джумшуд гызы 1 , \\ gultar_nasibova_1@yahoo.com
}

\author{
Мухтарова Хураман Зиядхан гызы 1 , \\ mukhtarova.khuraman@mail.ru \\ 1 Азербайджанский Государственный университет нефти и промышленности, \\ Азербайджан, AZE1010, г. Баку, пр. Азадлыг, 34.
}

В целях качественной оценки интенсивности территориального распределения напряжений сжатия, являющихся геодинамическим фактором в Шамахы-Гобустанской впадине, изучения их влияния на пликативные и дизъюнктивные дислокации, а также грязевой вулканизм были изучены морфологические особенности распространённых здесь локальных поднятий и грязевых вулканов, на основании полученных результатов были построены карты, показывающие особенности изменения величин амплитуд разломов, осложняющих структуры, а также карты изоморф, отражающие территориальное распределение напряжений сжатия в пределах стратиграфических единиц мела для северной, майкопа - для центральной и продуктивной толщи (ПТ) - нижний плиоцен ( $\left.\mathrm{N}_{2}{ }^{1} b\right)$ - для южной зон. Исследования выявили, что конусы грязевых вулканов, распространённых в северной зоне, где проявляются интенсивнье напряжения сжатия, относительно меньше конусов грязевых вулканов, принадлежащих центральной зоне, а размеры конусов южной зоны больше, то есть размеры конусов увеличиваются с севера на юг в направлении уменьшения интенсивности напряжений сжатия. Следует отметить, что это также можно связать с благоприятным изменением в том же направлении литофациального состава разреза, который является одним из основных факторов в образовании грязевых вулканов. С иелью определения роли литофациального фактора в образовании как грязевых вулканов, так и разломов различного вида на территории исследования на основании сводного литостратиграффического разреза был построен графрик, отражающий содержание глинистости и карбонатности в соответствующих стратиграфрических временных интервалах. Наряду с этим были также построены карты, отражающие естественные нефртегазопроявления и данные скважин по исследуемым зонам Шамахы-Гобустанской впадины где широко развиты природные нефртегазопроявления различного вида и происхождения, и на основании проведенных исследований для каждой зоны была установлена связь нефтеегазопроявлений с пликативными и дизъюнктивными дислокациями, физико-механических свойств комплексов пород с динамическими процессами.

Актуальность. Шамахы-Гобустанская впадина, расположенная в юго-восточной части мегаантиклинориума Большого Кавказа, отличается сложным тектоническим строением. По своим геоморфологическим, тектоническим, литологостратиграфическим особенностям, а также нефтегазоносности впадина делится на северо-, центрально-, юго-западно-, юго-восточногобустанские и Алятскую тектонические зоны. Развитые в этих зонах локальные поднятия осложнены высокоамплитудными надвигами и тектоническими покровами. Изучение влияния напряжений сжатия (которые являются геодинамическим фрактором) на пликативные и дизъюнктивные дислокации, грязевой вулканизм и нефртегазоносность по зонам территории исследования выделяется своей актуальностью. В пределах впадины с севера на юг с ослаблением интенсивности напряжений сжатия наблюдается увеличение перспектив нефртегазоносности территории. Причиной, как правило, является миграция флюидов в направлении от зон высокого давления к зонам низкого давления. Вместе с тем, наряду с геодинамическим фрактором, причинами высокой перспективности южной зоны территории исследования являются увеличение мощности майкопских, чокракских и отложений ПТ в южном направлении и распространение горизонтов песчаных коллекторов достаточно высокой мощности в литологическом составе.

Целью исследования является изучение особенностей территориального распределения основного геодинамического фрактора - сжимающих напряжений, которые играют большую роль в формировании и развитии локальных поднятий и осложняющих их нарушений разного типа, в том числе грязевых вулканов, а также в распределении нефтегазовых месторождений в пределах Шамахы-Гобустанской впадины.

Объекты: структуры и их литофациальный состав, формируемые мезозойскими отложениями в северной, палеогенмиоценовыми - в центральной и плиоценовыми - в южной зонах Шамахы-Гобустанской впадины.

Методы. Используя особенности изменения морфологии складок, развитых в Шамахы-Гобустанской впадине, наряду с изоморфными картами для поверхностей мела, майкопа и плиоцена, северной, центральной и южной зон, также были построены карты, отражающие величины амплитуд разломов, схема перспектив нефтегазоносности территории, была проведена оценка влияния интенсивности распределения сжимающих напряжений в каждой зоне.

Результаты. Являющиеся геодинамическим фактором напряжения сжатия сыграли значительную роль в формировании структурно-тектонического плана осадочного чехла Шамахы-Гобустанского синклинория. Локальные поднятия, развитые во всех трех зонах Шамахы-Гобустанской впадины, сфрормировались под влиянием как продольного, так и поперечного механизмов изгиба; широкое развитие грязевого вулканизма, являющегося показателем нефртегазоносности, в пределах ШамахыГобустанского синклинория и многочисленные естественные нефртегазовые выходы дают возможность высокой оценки перспектив нефтегазоносности автохтонных крыльев структур надвигового и покровного типов; ввиду непосредственного влияния особенностей распределения напряжений сжатия на миграцию фрлидов и образование скоплений, в зависимости от геодинамического режима в осадочном чехле, наблюдается ослабление интенсивности напряжений сжатия и увеличение нефтегазоносности территории с севера на юг.

\section{Ключевые слова:}

Мощность, песчанистость, перспективность, зона, структура, отложения, амплитуда, возраст, толща, тектоническое нарушение, надвие, кливаж, нефрть, газ. 


\section{Введение}

Шамахы-Гобустанская впадина, расположенная в юго-восточной части мегаантиклинория Большого Кавказа, отличается сложной тектонической структурой (рис. 1). По своим геоморфологическим, тектоническим, литолого-стратиграфическим особенностям, а также нефтегазоносности впадина разделяется на Северный, Центральный, Юго-Западный, Юго-Восточный Гобустан и Алятскую тектоническую зоны [1].

В Северной зоне обширно развиты складки мелового возраста и осложнены крупными надвигами и крупномасштабными кливажами [1].

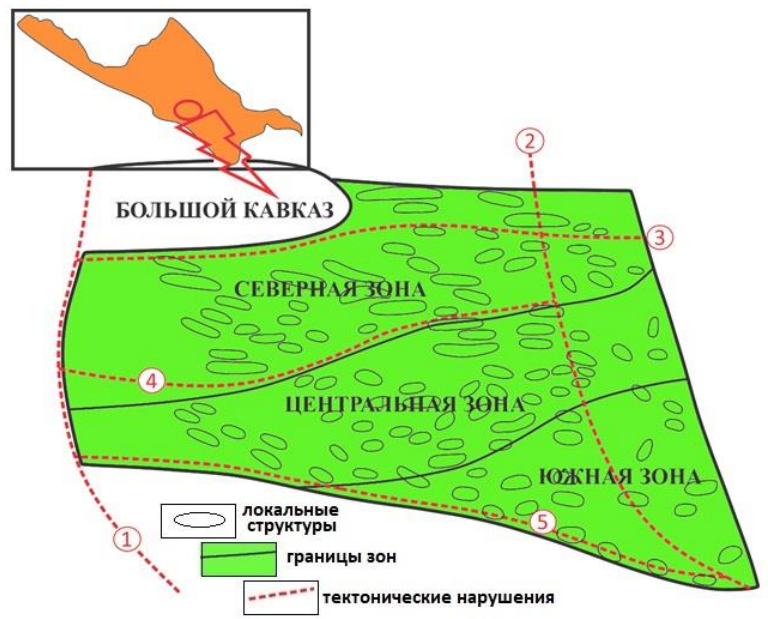

Puc. 1. Обзорная карта Шамахы-Гобустанской впадины. Тектонические нарушения [1]: 1 - ЗападноКаспийский; 2 - Яиминский; 3 - МалкамудГермианский; 4 - Занги-Горадильский; 5 Аджичай-Алятский

Fig. 1. Sightseeing map of the Shamakhy-Gobustan depression [1]. 1 - West Caspian; 2 - Yashma; 3 -MalkamudHermian; 4 - Zangi-Goradil; 5 -Adjichay-Alat

Преобладающие структуры надвигов образуют ступенчатость, которая резко отличает весь этот нефтегазоносный район (всю впадину) от соседних территорий. Северная зона всей впадины характеризуется обширным развитием терригенно-карбонатных пород мелового возраста.

В Центральной зоне развиты складки, связанные с палеоген-миоценовыми породами, которые простираются в субширотном направлении, характеризуются резкой асимметрией и осложнены продольными разрывами и надвигами [2].

В зоне Юго-Западного Гобустана локальные поднятия связаны с отложениями олигоцен-миоценового возраста. Одна из отличительных характеристик зоны заключается в том, что складки, сформировавшиеся здесь, осложнены продольными региональными разломами надвигового характера. Разломы осложнили в основном северные пологие крылья большинства локальных поднятий, и их северо-восточные крылья надвинуты на юго-западные под углом 30-75. Горизонтальная амплитуда разрывов достигает 1200 м [2].

Антиклинальные зоны Юго-Восточного Гобустана, состоящие из малочисленных и разбросанных корот- ких брахиантиклинальных и куполообразных локальных поднятий, связанны с отложениями плиоценового возраста. Тогда как часть этих поднятий повторяет ориентацию в общекавказском направлении палеоген-миоценовых структур Юго-Западного Гобустана, остальные простираются параллельно западному склону депрессии субмеридионального направления (Уталги, Мияджик, Анарт).

Следует отметить, что основной чертой, отличающей эту зону от остальных, является формирование грязевых вулканов на большинстве продольных разломов, осложняющих антиклинали [3-5].

Между Юго-Восточным Гобустаном и Нижнекуринской впадиной расположена Алятская тектоническая зона сложного тектонического строения. Зона осложнена продольным региональным тектоническим разломом с амплитудой 1500-1900 м, в результате чего на крутозалегающем юго-западном крыле на дневную поверхность выступили отложения абшеронского, а на северо-восточном крыле - плиоценового возраста. Поднятия этой зоны также осложнены продольно простирающимися разрывными нарушениями с развитыми грязевыми вулканами и грифонами [5].

\section{О методике исследования}

\section{структурно-тектонических особенностей}

Развитие в пределах имеющего сложное структурно-тектоническое строение Шамахы-Гобустанского синклинориума складок различного морфологического строения и их осложнение взбросовыми, надвиговыми, покровными и сдвиговыми нарушениями, а также широкое развитие грязевого вулканизма указывает на подверженность данной территории интенсивным тектоническим, геодинамическим процессам и сжимающим напряжениям высокой интенсивности.

Причиной же тому является расположение данного структурного элемента в относительной близости к сводовой зоне юго-западного крыла Большого Кавказа [4].

Основная цель исследования заключается в детальном изучении локальных поднятий и осложняющих их тектонических нарушений различного типа, а также особенностей территориального распределения сжимающих напряжений, играющих основную роль в формировании и развитии грязевого вулканизма.

В целях качественной оценки интенсивности распределения сжимающих напряжений по всей территории были построены карты изоморф, отображающие территориальное распределение сжимающих напряжений, для отдельных стратиграфических единиц мела, майкопа и продуктивной толщи (ПТ) и карты, отражающие величины амплитуд тектонических нарушений, осложняющих структуры (рис. 2, 3).

Проведенные исследования показали, что на основании особенностей тектонического и геодинамического режимов развития юго-восточного погружения Большого Кавказа, в связи с близостью расположения развитых в мезозое локальных поднятий к осевой зоне Большого Кавказа, территория подверглась большему воздействию сжимающих напряжений, в результате чего большинство структур являются линейно вытянутыми, удлиненными брахиформами, 
осложненными нарушениями надвигового, покровного, сдвигового видов.

Несмотря на то, что большинство локальных структур, развитых в майкопских отложениях, являются короткими брахиформами, осложненными надвиговыми нарушениями, здесь также развиты изометрические складки [6].

Ввиду того, что локальные поднятия ПТ сформировались вдали от зоны интенсивного развития сжимающих напряжений, они осложнены радиально направленными сбросовыми и взбросовыми нарушениями.

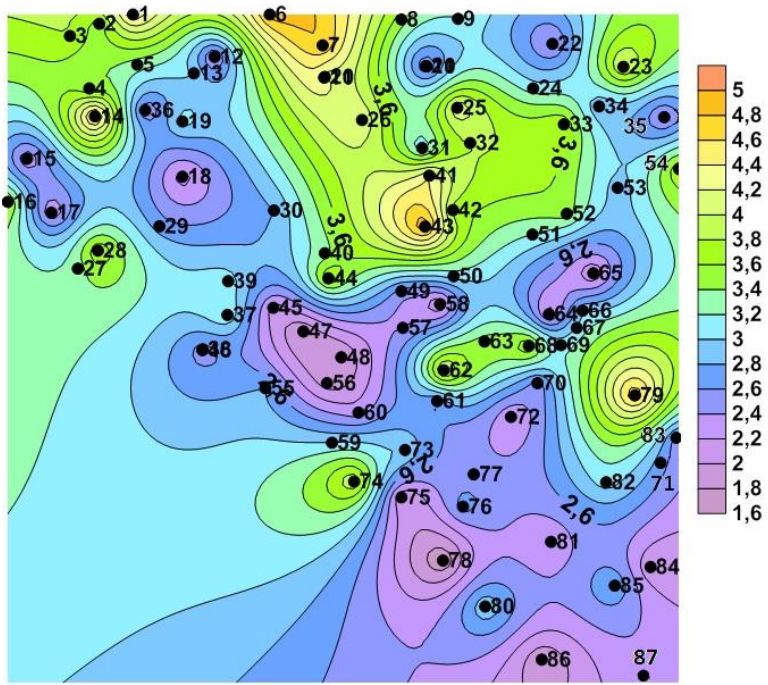

Развитые в пределах трех поверхностей (мезозой, майкоп, ПТ) изучаемые локальные поднятия с отличающейся морфологией, осложненные нарушениями различной амплитуды и грязевыми вулканами, в действительности сформировались в зонах с различной территориальной интенсивностью сжимающих напряжений [6].

Этот факт подтверждается конфигурацией карт изоморф и изменением величин амплитуд нарушений, составленных для упомянутых поверхностей (рис. 2, 3)

Так, от более древних к молодым, изолинии по поверхности мезозоя характеризуются большей плотностью, по поверхности майкопа - относительной разреженностью, а по поверхности ПТ - сильной разреженностью. Помимо этого, большая амплитуда нарушений в 500-2000 м, осложняющих структуры в ме30зое, постепенно убывает до 300-700 м в майкопе, а в ПТ составляет 150-1900 м (рис. 3).

Причинами же падения амплитуды в направлении с севера на юг могут быть убывание интенсивности сжимающих напряжений в этом направлении, а также литофациальный состав осадочной толщи и уменьшение твердости пород, оказывающих влияние на развитие нарушений. Следует отметить, что в пределах северного склона впадины, т. е. в территориях, наиболее близко и параллельно расположенных к осевой линии Большого Кавказа, развиты грязевые вулканы Гызмейдан, Кюрдемич, Гарагезлю, Набур (рис. 4) и др. [2].

Рис. 2. Изоморфная карта локальных поднятий по отдельным зонам Шамахы-Гобустанской впадины. Коэффициент изоморфности: Северная зона - 2,2-5; Центральная зона - 2,2-4,2; Южная зона - 1,6-2,8. Название структур: 1 Сарыташчай; 2 - Пирбейли; 3 - Ени Гызмейдан; 4 - Тальпнуру; 5 - Гызмейдан; 6 - Ангелан; 7 - Кемчи; 8 Гермиян; 9 - Гядису; 10 - Кюркечидаг; 11 - Гаджили; 12 -Арпабулаг; 13 - Тюрфе; 14 - Энгихаран; 15 - Гаравелли; 16 - Чархи; 17 - Сагиян; 18 - Ковбулак; 19 - Хилмилли; 20 - Алаташ; 21 - Гараязы; 22 - Кюркечидаг-Шерги; 23 - Г.3. Тагиев; 24 - Гарадаг-Шерги; 25 - Габандаг-Герби; 26 - Горадиль; 27 - Гойлер; 28 Чанган; 29 - Медресе; 30 - Мерезе; 31 - Набур; 32 - Гибледаг; 33 - Агбурун-Шерги; 34 - Агбурун-Герби; 35 Юнусдаг; 36 - Гаджили-Джануб; 37 - Хыдырлы; 38 - Гушчу; 39 - Екехана; 40 - Гаиблер-Шаиблер; 41 - Гараджюзлу; 42 - Дженгичай; 43 - Илхыдаг; 44 - Шыхзеирли; 45 - Явандаг; 46 - Гиджекиахтарма; 47 - Гиан; 48 - Шейтануд; 49 - Байгуштин; 50 - Джануб-Алаташ; 51 - Бабаджан; 52 - Нафтик; 53 - Гёйтепе; 54 Элинджа-Готурдаг; 55 - Гюнгёрмез; 56 - Сюнду; 57 - Гаргабазар; 58 - Донгузлуг; 59 - Дашмердан; 60 Адживелли-Шерги; 61 - Чеильдаг; 62 - Чеильахтарма; 63 - Нардаранахтарма; 64 - Борансыз Бояната; 65 Боздаг; 66 - Шорбулаг; 67 - Чулга; 68 - Гарыгышлаг; 69 - Теклк; 70 - Чеильдаг; 71 - Мияджик; 72 - Кафтаран; 73 - Илхычы; 74 - Шекихан; 75 - Эрзаны-Гылыч; 76 -Торагай; 77 - Умбакы; 78 - Беридаш; 79 - Шихигая; 80 - Айрантёкен; 81 - Дуванны-Герби; 82 - Утальги; 83 - Анарт; 84 - Кенизедаг; 85 - Дуванны; 86 Готурдаг; 87 - Дашииль

Fig. 2. Isomorphic map of local uplifts by individual zones of Shamakhy-Gobustan depression. Isomorphism coefficient: Northern zone - 2,2-5; Central zone - 2,2-4,2; South zone - 1,6-2,8. Name of structures: 1 -Sarytashchay; 2 - Pirbeyli; 3 - Yeni Gizmeidan; 4 -Talishnuru; 5 - Gizmeidan; 6-Angelan; 7 - Kemchi; 8-Germiyan; 9 - Gyadisu; 10-Kyurkechidag; 11 Hajili; 12 - Arpabulag; 13 - Tyurfe; 14 -Engikharan; 15 - Garavelli; 16 -Charkhi; 17 -Saghiyan; 18-Kovbulak; $19-$ Hilmilli; 20 - Alatash; 21 - Garayazy; 22 - Kyurkechidag-Shergi; 23 - G.Z. Tagiyev; 24 - Garadag-Shergi; 25 - Gabandag-Gerbi; 26 - Goradil; 27 - Goiler; 28 - Changan; 29 -Madrasah; 30 - Mereze; 31 - Nabur; 32 - Gibledag; 33 - Agburun-Shergi; 34 - Agburun-Gerbi; 35 - Yunusdag; 36 - Hajili-Janub; 37 - Khidirli; 38 - Gushchu; 39 - Ekehana; 40 Gaibler-Shaibler; 41 - Garajuzlu; 42 - Dzhengichay; 43 - Ilhydag; 44 - Shikhzeirli; 45 - Yavandag; 46 - Gidzhekiakhtarma; 47 - Gian; 48 - Sheitanud; 49 - Baygushtin; 50 - Janub-Alatash; 51 - Babajan; 52 - Naftik; 53 - Goytepe; 54 Elinja-Goturdag; 55 - Gyungermez; 56 - Syundu; 57 - Gargabazar; 58 - Donguzlug; 59 - Dashmerdan; 60 - AgivelliShergi; 61 - Cheildag; 62 - Cheilakhtarma; 63 -Nardaranakhtarma; 64 - Boransyz Boyanata; 65 - Bozdag; 66 - Shorbulag; 67-Chulgaishlag; 68 - Garygyshlag ; 69-Teklk; 70 - Cheildag; 71 -Miyadzhik; 72 - Kaftaran; 73 - Ilkhychi; 74 Shekihan; 75 - Erzany-Gylych; 76 - Toragay; 77 - Umbaki; 78 - Beridash; 79 - Shikhigaya; 80 - Ayrantöken ; 81 Duvanny-Gerbi; 82 - Utalgi; 83 - Anart; 84 - Kenizedag; 85 - Duvanny; 86 - Goturdag; 87 - Dashgil 


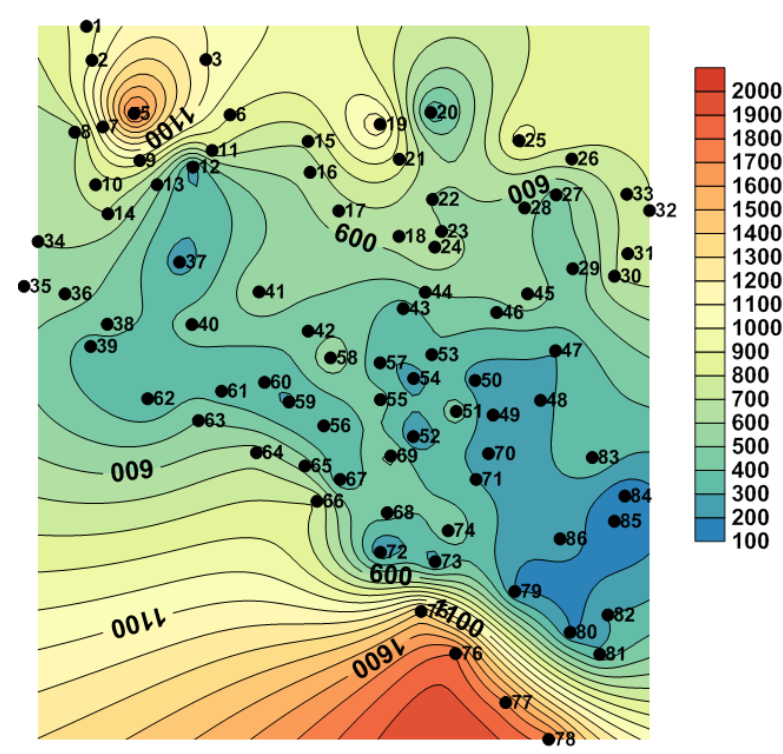

Рис. 3. Карта изменения величин амплитуды тектонических нарушений в Шамахы-Гобустанской впадине. Амплитуды разрывов: Северная зона 500-2000; Центральная зона - 300-700; Южная зона $-150-1900 \mathrm{M}$

Fig. 3. Map of changes in the magnitudes of the tectonic violations in the Shamakhy-Gobustan depression. Break amplitudes: Northern zone - 500-2000; Central zone-300-700; South zone -150-300 m

В центральной зоне, т. е. в наиболее восточном окончании южного крыла Большого Кавказа, развиты грязевые вулканы Нардаранахтарма, Шихзегирли, Шыхигайа, Гыргышлаг и ряд других (рис. 5).

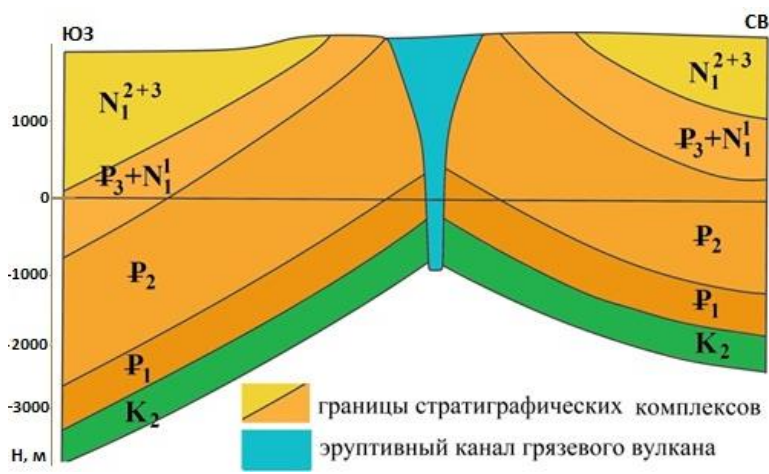

Puc. 4. Профиль грязевого вулкана Набур [7]

Fig. 4. Profile of Nabur Mud Volcano [7]

Графики, построенные по поверхности ПТ, охватывают в основном южную часть Гобустана. В этой зоне высота конусов грязевых вулканов колеблется между 150-250 м, и они отличаются от остальных своим развитием: Торагай (рис. 6), Кенизедаг, Девелидаг, Утальги, Чапылмыш, Шиштепе и др. [1, 2].

Следует отметить, что в направлении от Северной зоны к Южной интенсивность пликативных и дизъюнктивных дислокаций падает и происходит омоложение осадочных толщ. Резкое изменение шарниров антиклинальных зон, видов продольных нарушений и их амплитуд характерно для всей территории. Горадильский надвиг, простирающийся вдоль границы
Центральной и Северной зон, является самым крупным среди вышеупомянутых [2].

С целью изучения степени воздействия сжимающих напряжений на пликативные, дизъюнктивные дислокации и грязевой вулканизм в пределах территории были исследованы морфологические особенности грязевых вулканов, развитых здесь. Конусы развитых в Северной зоне грязевых вулканов, где интенсивно проявляются сжимающие напряжения, привлекают внимание относительно меньшими размерами по сравнению с конусами грязевых вулканов Центральной зоны.

Конусы грязевых вулканов Южной зоны выделяются большими размерами. Нужно отметить, что с севера на юг, т. е. в направлении угасания интенсивности сжимающих напряжений, наблюдается увеличение и размеров, и диаметра конусов грязевых вулканов. Вдобавок это можно связать с «благоприятным» изменением литофациального состава разреза в данном направлении, что является одним из немаловажных факторов для образования грязевых вулканов.

Для определения роли литофациального фактора в образовании как грязевых вулканов, так и нарушений различного вида в пределах рассматриваемых стратиграфических интервалов на основании сводного нормального литолого-стратиграфического разреза был составлен количественный график глинистости и карбонатности.

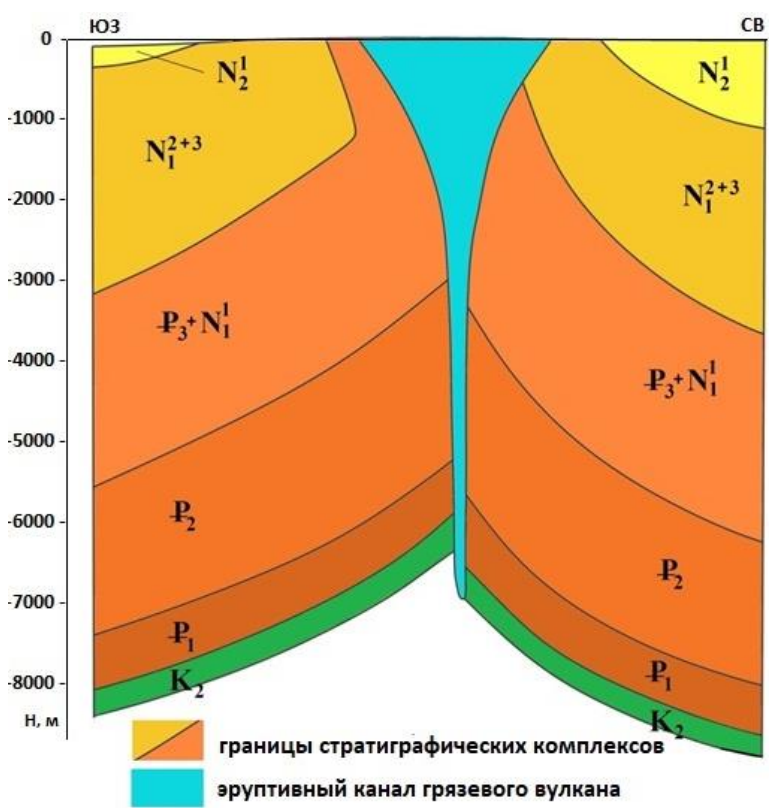

Рис. 5. Профиль грязевого вулкана Нардаранахтарма [7]

Fig. 5. Profile of Nardaranakhtarma Mud Volcano [7]

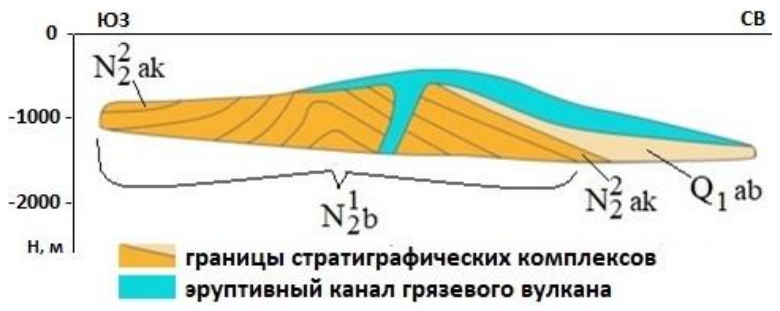

Рис. 6. Профиль грязевого вулкана Торагай [7]

Fig. 6. Profile of Toragay Mud Volcano [7] 
По графику видно, что глинистость терригеннокарбонатных отложений мезозойского возраста, составляет $48 \%$, что намного меньше в сравнении с отложениями майкопа и ПТ.

Отложениям майкопа характерна глинистость в $65 \%$, а разрезу ПТ - $71 \%$. Отметим, что обратно пропорциональная глинистости карбонатность составляет, соответственно, 23, 10 и $8 \%$ (рис. 7).

Изменение литологического состава пород в подобной форме, увеличение размеров конусов грязевых вулканов от Северной зоны в южном и юго-западном направлениях могут быть связаны с увеличением объема некомпонентных пород в этом же направлении в комплексах отложений различного возраста.

Алятская тектоническая зона, охватывающая югозападную часть Гобустана, характеризуется сложным тектоническим строением и широким развитием грязевого вулканизма. Здесь сформировались грязевые вулканы: Дашмярдан, Солахай, Айрантекян, Готурдаг, Гырдаг и др. Амплитуда продольного нарушения, с которым связаны эти вулканы, колеблется в пределах $1400-1600$ м [8].

Исследования показали, что большинство локальных поднятий, развитых в комплексе кайнозойских отложений впадины, имеют инъективное, т. е. диапировое, происхождение. Развитие складок такого типа имеет конседиментационный характер и происходит под воздействием механизма поперечного изгиба. Но, ввиду того, что впадина расположена вблизи зоны коллизии, в формировании локальных поднятий на её территории в определенной степени участвуют и сжимающие напряжения, т. е. механизм продольного изгиба $[9,10]$.

Роль механизма продольного изгиба в развитии диапировых складок находит свое отражение в морфологии этих складок.

Например, изометрическая форма складок указывает на практическое отсутствие в их формировании механизма продольного изгиба. Известно, что для формирования диапировых складок основной причиной являются и активность механизма продольного изгиба, и сжимающие напряжения. Зарождение же механизма продольного изгиба связано с наличием в пределах территории сжимающих напряжений. Учитывая соприкосновение впадины на севере с зоной коллизии, которая является источником сжимающих напряжений, а также относительно высокую глинистость осадочного чехла, широкое развитие грязевого вулканизма можно считать естественным.

Основным фактором для образования грязевых вулканов является наличие неуплотненной осадочной толщи, характеризующейся высокой пластичностью и большой мощностью, присутствием пластов глин. Разрез Шамахы-Гобустанской впадины, которая является территорией исследования, характеризуется 60-80 \% глинистостью. Наряду с этим в данном осадконакопительном бассейне присутствовали благоприятные структурно-тектонические и геодинамические условия для развития грязевого вулканизма [11-13].

Следует отметить, что самые крупные грязевые вулканы Шамахы-Гобустанской впадины сформировались в пределах Западной, Юго-Западной и Алят- ской тектонических зон (Дашмердан, Солахай, Айрантекан) (рис. 8-10) вдоль продольных и поперечных нарушений, на сводах, крыльях и переклиналях антиклинальных структур.

В южном и в юго-восточном направлениях роста интенсивности извержений наблюдается увеличение размеров конусов. Здесь крупность грязевых вулканов и интенсивность извержений связаны с подверженностью как Шамахы-Гобустанского синклинориума, так и Алят-Ленгебизской тектонической зоны сильному влиянию высокоинтенсивных сжимающих напряжений, возникающих в зонах Большого и Малого Кавказа, и Талыша [14-16].

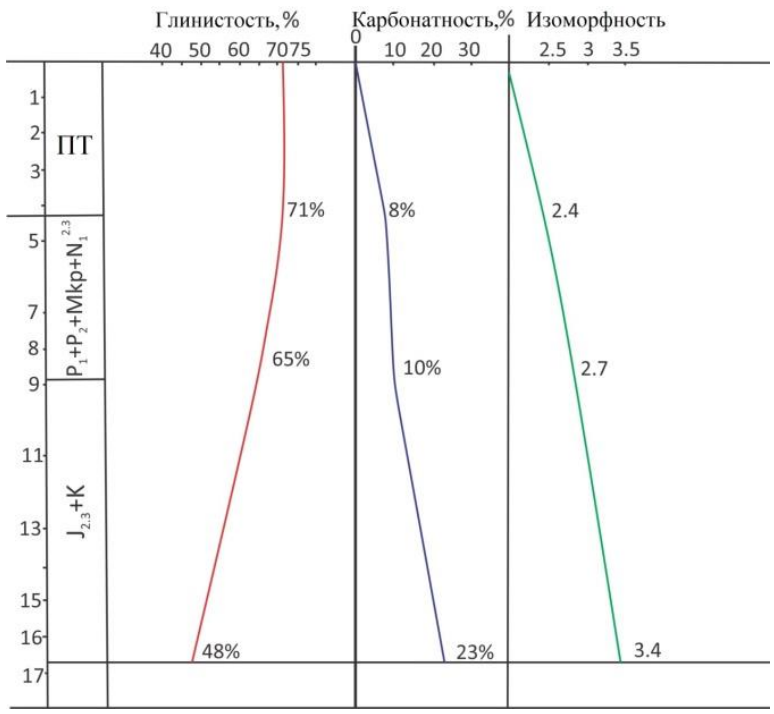

Рис. 7. Изменение глинистости и карбонатности по глубине

Fig. 7. Change of clay and carbonate content in depth

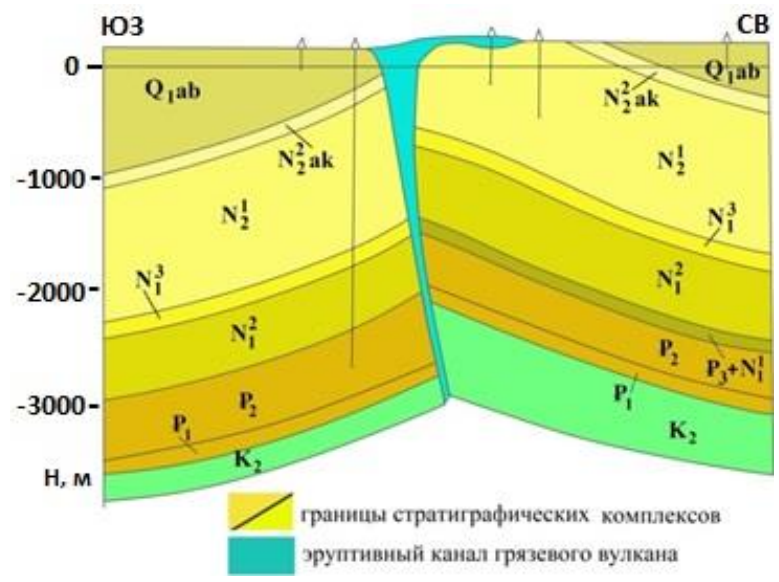

Pис. 8. Профиль грязевого вулкана Дашмярдан [7]

Fig. 8. Profile of Dashmardan Mud Volcano [7]

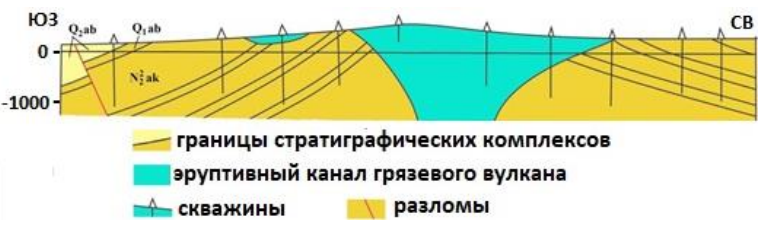

Pис. 9. Профиль грязевого вулкана Солахай [7]

Fig. 9. Profile of Solakhay Mud Volcano [7] 
Как известно, на первичных этапах, в результате внешнего воздействия, пласты, подвергшись в основном пликативным дислокациям, образуют складки различного вида и морфологии. Если их образование односторонне протекает путем механизма продольного изгиба, осевая поверхность складки будет тяготеть в сторону, противоположную направлению наиболее сильного воздействия.

В результате же продолжительного воздействия силы складка будет формироваться вначале как косая, перейдя в дальнейшем в опрокинутую и далее в лежачую. Дальнейшее развитие складки определяется особенностями составляющих её комплексов пород.

Так, например, если комплекс пород составлен в основном некомпетентными пластами, складка, приняв лежачее положение, в условиях продолжения внешнего воздействия, принимает положение перевернутой складки. Это происходит в случаях, когда пласты, составляющие структуру, представлены пластичными породами.

В таких случаях, несмотря на возникновение напряжений растяжения в сводовой части складки, переход образовавшейся там относительно плотной сети трещин в разрывные дислокации менее вероятен, ввиду того, что пласты некомпетентных пород более склонны к пластическим деформациям. В этой ситуации вероятность преобразования лежачей складки в период своего дальнейшего развития в перевернутую выше.

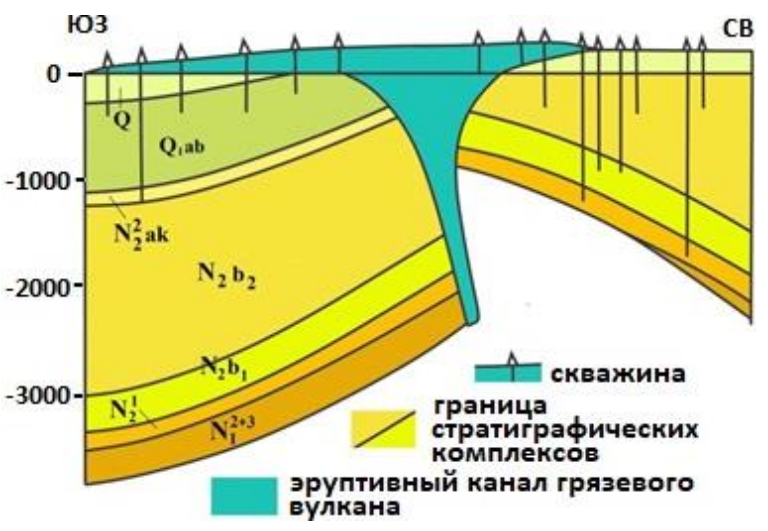

Pис. 10. Профиль грязевого вулкана Айрантекан [7]

Fig. 10. Profile of Ayrantekan Mud Volcano [7]

В случае когда породы комплексов, составляющих складку, характеризуются относительной твердостью, т. е. компетентностью, либо если в разрезе пластичные слои составляют меньшинство, из-за напряжений растяжения, возникших в сводовой части складки, первично возникшая здесь относительно плотная сеть трещин в результате продолжительного воздействия внешнего влияния в этой же зоне станет причиной нарушения целостности пластов и, как следствие, формирования надвигового нарушения перемещением висячего крыла по поверхности разрыва в направлении воздействия сжимающих напряжений на лежачее крыло.

Следует отметить, что надвиг (а также шарьяж) это, в действительности, развитие пликативной дислокации, т. е. развитие складки в направлении дизьюнктивно-разрывной дислокации. В таких ситуациях, с точки зрения нефтегазоносности, перспективными могут быть принимающие участие в строении надвига коллекторы лежачего крыла, а в случае развития до покрова - автохтон (из-за экранирования аллохтоном).

Таким образом, остаточная (пластичная либо хрупкая) деформация, возникшая в породах как результат внешнего воздействия, в значительной степени зависит от их физических свойств, т. е. компетентности или некомпетентности.

Ввиду предрасположенности пластов, составленных из компетентных пород, хрупкой деформации под воздействием сжимающих напряжений, становятся причиной формирования дизъюнктивной дислокации при развитии складки.

Пласты некомпетентных пород при продолженном внешнем воздействии на составленную ими складку являются причиной образования складок различной морфологии в результате пликативной деформации.

Северная тектоническая зона ШамахыГобустанской впадины, как отмечалось ранее, выделяется широким развитием структур мелового возраста, и здесь сформировались в основном компетентные терригенно-карбонатные отложения. Из-за этого развитые здесь под воздействием сжимающих напряжений локальные поднятия осложнены в основном нарушениями надвигового, покровного и сдвигового видов. Большая амплитуда этих нарушений указывает на интенсивность формирующих их сжимающих напряжений.

Осадочный комплекс Центрального Гобустана был накоплен в условиях воздымания осевой зоны Юго-Восточного Кавказа и глубокого погружения окружающих впадин [4], а накопленные пластичные слои глин подверглись интенсивному складкообразованию и дизъюнктивным дислокациям. Эти пластичные глинистые массы, вытесняясь кверху, стали причиной образования диапировых структур. Здесь, как правило, по всем антиклинальным структурам проходят продольные нарушения, в результате чего северовосточное (аллахтонное) крыло залегает на югозападном (автохтонном). Наряду с этим, оба крыла были раздроблены на тектонические блоки поперечными нарушениями. Малая, по сравнению с Северной зоной, амплитуда нарушений, осложняющих антиклинальные складки субширотного простирания палеоген-миоценовых отложений в Центральном Гобустане, связана, соответственно, с относительно слабой интенсивностью сжимающих напряжений на данной территории и более широким развитием некомпетентных пород.

Олигоцен-миоценовые отложения как ЮгоЗападного, так и Центрального Гобустана осложнены брахиантиклинальными складками. Для локальных поднятий данной зоны также характерно осложнение региональными продольными нарушениями. Амплитуда нарушений взбросового и надвигового видов, в сравнении с Центральной зоной, меньше. Естественные выходы нефти и газа, а также проявления грязевых вулканов, широко развитых в Юго-Западном Гобустане, в сводном разрезе которого преобладают глины, связаны с тектоническими нарушениями [17-20]. 
В Юго-Восточном Гобустане короткие брахиантиклинали и куполообразные поднятия разделены на мелкие антиклинальные зоны, характеризующиеся малым количеством и разбросанным расположением. Одной из основных особенностей Юго-Восточного Гобустана является различное простирание его антиклиналей. Так, некоторые поднятия, повторяя общекавказское направление палеоген-миоценовых поднятий Юго-Западного Гобустана, имеют унаследованный характер (Дуванный, Кянизадаг, Торагай, Чеильахтарма и др.). Другие же поднятия (Уталги, Шихигая, Анарт), простираясь в субмеридиональном направлении, сформировались параллельно западному склону. Такая ориентация этих складок указывает на их дисгармоничность либо же отсутствие у них глубоких корней.

Одновременно Юго-Восточный Гобустан отличается широким распространением грязевых вулканов, связанных с продольными нарушениями, осложняющими антиклинали. Поперечные и радиальные нарушения, осложняющие некоторые антиклинальные складки, затухают с глубиной в низах плиоцена, не доходя до миоценовых пород [2]. Это позволяет высказать мнение о том, что данные структуры имеют короткую брахи- и изометрическую форму при более активном воздействии механизма поперечного изгиба в их формировании. Можно предположить осложнение диапировых складок или складок, осложненных грязевым вулканизмом, радиальными нарушениями за счет возникновения напряжений растяжения в сводовой части в результате перемещения пластичных глинистых слоев вверх.

Территория Шамахы-Гобустанской впадины характеризуется широким распространением естественных нефтегазопроявлений различного вида и происхождения. Проведенные исследования выявили для этих зон связь нефтегазопроявлений, пликативных и дизъюнктивных дислокаций, a также физикомеханических свойств комплексов пород с геодинамическими процессами.

Известные нефтегазопроявления Северной зоны, где развиты локальные поднятия мезозойских отложений, связаны с развитыми здесь различными нарушениями [2], а Центрального Гобустана - с песчаноалевритовыми породами-коллекторами палеогена, обнажающимися в сводовой части антиклиналей. В узкой южной полосе, примыкающей к северному склону Джейранкечмезской впадины данной зоны, наблюдаются выходы нефти и газа, связанные с нижне- и среднемиоценовыми отложениями.

Тогда как в пределах Юго-Западного Гобустана природные выходы нефти и газа связаны с пластамиколлекторами олигоцен-миоценовых отложений, в Юго-Восточной и Алятской тектонической зонах они наблюдаются в сводовых частях отдельных поднятий в дневных обнажениях нефтяных пород песчанистоалевролитового состава, относящихся к различным интервалам ПТ $[8,9]$.

Вышеуказанные нефтегазопроявления имеют большое значение для проведения структурнокартировочных работ на отдельных участках терри- тории, бурения и испытания поисково-разведочных скважин в целях оценки перспектив нефтегазоносности стратиграфических единиц мезокайнозойских отложений Шамахы-Гобустана.

Проведенные исследования по этому направлению показывают, что вследствие неравномерности степени их изученности уровень их описания неодинаков. Однако следует учесть, что даже крайне незначительные признаки нефтегазоносности могут сыграть важную роль в сравнительной оценке перспектив нефтегазоносности отдельных стратиграфических единиц (например, мел, палеоген-миоцен, плиоцен) [8].

В Северной зоне, где сжимающие напряжения интенсивны, нефтегазоносность отмечается только в разрезах пробуренных скважин в виде слабых проявлений. Нужно учесть, что широкое развитие по всей территории сальз, грифонов и сопок является важным признаком, отрицательно влияющим на нефтегазоносность. Дело в том, что в результате воздействия сжимающих напряжений на осадочный чехол впадины часть флюидов, вытесняясь и выходя на поверхность земли по тектоническим нарушениям и сети трещин, а часть мигрируя в зоны слабого воздействия сжимающих напряжений, являются причиной разрушения месторождений $[20,21]$. Вместе с тем на изучаемой территории надвиги с большими амплитудами могут сыграть важную роль в перспективах её нефтегазоносности, обусловленной сохранением залежей углеводородов в коллекторах лежащих крыльев.

В Центральной зоне, где, по сравнению с Северной зоной, сжимающие напряжения имеют относительно слабый характер, в разрезах скважин наблюдались интенсивные нефтегазопроявления и промышленные притоки. В Южной зоне, с более слабой интенсивностью сжимающих напряжений, находятся основные эксплуатируемые месторождения и структуры со скважинами, из которых получены притоки промышленного значения [1].

Можно прийти к выводу, что с севера к югу, в направлении затухания интенсивности сжимающих напряжений, перспективы нефтегазоносности растут. Причиной, как правило, является миграция флюидов из зон высокого давления в зоны низкого давления.

Следует отметить, что наряду с геодинамическим фактором увеличение мощности отложений майкопа, чокрака и ПТ в южном направлении, а также наличие в их составе горизонтов песчаных коллекторов достаточной мощности сыграли свою роль в выделении Южного Гобустана в качестве высокоперспективной зоны.

\section{Выводы}

1. Сжимающие напряжения, являющиеся геодинамическим фактором, сыграли важную роль в формировании структурно-тектонического плана осадочного чехла Шамахы-Гобустанской впадины.

2. Локальные поднятия, развитые во всех трех зонах Шамахы-Гобустанской впадины, сформировались в результате механизмов продольного и поперечного изгиба.

3. В связи с тем, что большая часть осадочного чехла территории составлена чередованием терри- 
генных и карбонатных пород, подверженных пликативным и дизъюнктивным дислокациям, здесь в основном распространены слоистые природные резервуары гранулярного и ловушки структурнотектонического типов.

4. Учитывая широкое развитие грязевого вулканизма и многочисленных естественных выходов нефти и газа как показателей нефтегазоносности в пределах Шамахы-Гобустанского синклинориума, здесь высоко могут быть оценены перспективы нефте-

\section{СПИСОК ЛИТЕРАТУРЫ}

1. Юсифов Х.М. Нефтегазоносность и неантиклинальные ловушки палеоген-миоценовых отложений ШамахыГобустана. - Баку: Марс Принт, 2016. - 204 с.

2. Геологичесие основы поисков нефтегазовых месторождений в палеоген-миоценовых отложениях Восточного Азербайджана / Х.М. Юсифов, Р.Р. Рахманов, С.Б. Мамедов, А.А. Эфендиев // Геолог Азербайджана. - 2006. - № 1. - С. 46-63.

3. Юсифов Х.М., Рахманов Р.Р. Выбор направления поисковоразведочных работ и уточнение геологического строения и перспективности мезокайнозойских отложений ЮгоВосточного Гобустана-Западного Абшерона: заключительный отчет научно-исследовательской работы НИИГНКАР. - Баку, 2008. $-208 \mathrm{c}$.

4. Юсифов Х.М., Эфендиев А.А., Мамедов С.Б. Перспективные направления и анализ комплексного геолого-геофизического изучения палеоген-миоценовых отложений юго-восточной части Большого Кавказа // Научные работы НИИГНКАР. 2006. - № 6. - C. 25-35.

5. Алиев Ад.А. Грязевой вулканизм Южно-Каспийского нефтегазоносного бассейна // Геология и полезные ископаемые Мирового океана. - 2006. - № 3. - С. 12-21.

6. Нариманов Н.Р., Насибова Г.Д., Мансурова С.И. Геодинамический режим формирования структурного плана и нефтегазоносности Шемаха-Гобустанского синклинория // Геология, геофизика и разработка нефтяных и газовых месторождений. - 2017. - № 6. - С. 17-23.

7. Atlas of the world mud volcanoes / Ad.A. Aliyev, I.S. Guliyev, F.N. Dadashev, R.R. Rakhmanov. - Baku: Nafta-Press, 2015. $205 \mathrm{p}$.

8. Гусейнов Б.Б., Салманов А.М., Магеррамов Б.И. Нефтегазогеологическое районирование территории суши Азербайджана. - Баку: Марс Принт, 2019. - 308 с.

9. Нариманов Н.Р. Геодинамическая обстановка обрамления Южно-Каспийской мегавпадины // Геолог Азербайджана. 2005. - № 10. - C. 26-32.

10. Нариманов Н.Р. Влияние геодинамических процессов на нефтегазообразование в Южно-Каспийской впадине // Азербайджанское Нефтяное Хозяйство. - 2008. - № 8. - С. 13-18.

11. Моделирование механизма генерации, аккумуляции и путей миграции углеводородов в Южно-Каспийской впадине / К.Н. Каграманов, Н.М Ганиев, Х.З. Мухтарова, М.Т. Бабаева // газоносности автохтонных крыльев надвиговых и покровных видов структур.

5. В зависимости от геодинамического режима в осадочном чехле ввиду непосредственного влияния особенностей распределения сжимающих напряжений на миграцию флюидов и образование скоплений с падением интенсивности сжимающих напряжений в направлении с севера на юг наблюдается рост нефтегазоносности.

Геология, геофизика и разработка нефтяных и газовых месторождений. - 2018. - № 6. - С. 37-45.

12. Prognosis of Baku archipelago hydrocarbon potential by types of mud volcanoes / N.R. Narimanov, G. Gahramanov, M.S. Babayev, S.G. Shpirco, G.J. Nasibova, K.Z. Mukhtarova // Вестник Киевского национального университета имени Т. Шевченко. Геология. -2019 . - № 4 (87). - С. 55-62.

13. Cenozoic stag of development of local structures of the Lower Kura Depression and Baku Archipelago related to their oil and gas perspectivity / N.R. Narimanov, N.A. Babayev, G. Gahramanov, Z. Javad-Zadeh // Geological Journal. - 2018, 2 July. - № 10. P. 337-341.

14. Geosciences of Azerbaijan / A.A. Alizadeh, I.S. Guliyev, F.A. Kadirov, L.V. Epelbaum // Economic Geology and Applied Geophysics, Springer International Publishing. - 2017. - V. I. № 10. - P. 340-351

15. Mukhtarova K.Z., Nasibova G.J., Ahmadov M.G. The role of South-Eastern Gobustan and Absheron depressions clays with rheologically active properties in formation of structures and mud volcanism // American Association Educational Researcher, Washington. - 2016, December. - № 9. - P. 673-678.

16. Yusifov M., Rabinowitz P. Classification of mud volcanoes in the South Caspian Basin, offshore Azerbaijan // Marine and Petroleum Geology. - 2014. - № 21 (8). - P. 965-975.

17. Buniat-zade Z.A. Gas and oil volcanism: genesis and classification // Proc. III International Conference of Azerbaijan Society of Oil Geologists. - Baku, 1995. - P. 5-6.

18. Kerimov A.A., Gusejnov G.M., Narimanov N.R. Geodynamical aspects of manifestations of diapirism and mud volcanism // Proct. III International Conference of Azerbaijan Society of Oil Geologists. - Baku, 1995. - P. 4-5.

19. Deep gases discharged from mud volcanoes of Azerbaijan: new geochemical evidence / M. Bonini, F. Tassi, A. Feyzullayev, C. Aliyev // Marine and Petroleum Geology. - 2013. - № 43. P. $450-463$.

20. Methane emission from mud volcanoes in Eastern Azerbaijan / G. Etiope, A. Feyzullayev, C. Baciu, A. Milkov // Geology. 2004. - № 32 (6). - P. 465-468.

21. Roberts K., Stewart S., Davies R. Sector collapse of mud volcanoes // Journal of the Geological Society. - 2011. - № 168 (1). P. $49-60$.

\section{Информация об авторах}

Насибова Г.Д., кандидат геолого-минералогических наук, доцент кафедры геологии нефти и газа, Азербайджанский Государственный университет нефти и промышленности.

Myxmapoвa X.3., кандидат геолого-минералогических наук, доцент кафедры геологии нефти и газа, Азербайджанский Государственный университет нефти и промышленности. 
UDC 553.98(479.24):550.8.072

\title{
OIL AND GAS PROSPECTS OF THE SHAMAKHY-GOBUSTAN DEPRESSION IN RELATION TO ITS STRUCTURAL AND TECTONIC PROPERTIES
}

\author{
Gultar Jumshud kizi Nasibova', \\ gultar_nasibova_1@yahoo.com \\ Khuraman Ziyadkhan kizi Mukhtarova ${ }^{1}$, \\ mukhtarova.khuraman@mail.ru \\ 1 Azerbaijan State Oil and Industry University, \\ 34, Azadlig avenue, Baku, AZ1010, Azerbaijan.
}

For quality assessment of intensity of the area distribution of compressional stresses (geodynamic factor in the Shamakhy-Gobustan depression) and to study its impact upon folding, faulting and mud volcanism, the authors have studied the morphological properties of locally developed uplifts and mud volcanoes, and based on the results obtained have built the maps showing the properties of the magnitude variation of the amplitudes of the faults complicating the structures as well as isomorphic maps reflecting area distribution of compressional stress within the stratigraphic units of the Cretaceous for the northern, Maikopian - for the central and Productive Series - for the southern zones. The studies have revealed that the cones of mud volcanoes, common in the northern zone, where intense compressional stresses are manifested, are relatively smaller than the cones of mud volcanoes of the central zone, and those of the southern zone are larger, that is, the cone dimensions increase from north to south in the direction of decreasing intensity of compressional stresses. It should be noted that this can also be associated with a favorable change in the lithofacies composition of the section in the same direction, which is one of the main factors in the formation of mud volcanoes. In order to determine the role of the lithofacies factor in the formation of both mud volcanoes and faults of various types within the study area, based on the composite lithostratigraphic section the authors drawn the diagram, reflecting the clay and carbonate content in the corresponding stratigraphic time intervals. At the same time the maps reflecting natural oil and gas shows and well data for the zones of the Shamakhy-Gobustan depression under study, where natural oil and gas shows of various types and origin are widespread, were made and based on the studies carried out for each zone, association of oil and gas shows with folding and faulting as well as that of the physical and mechanical properties of rock complexes with geodynamic processes were established.

Relevance. The Shamakhy-Gobustan depression, located in the southeastern part of the Greater Caucasus megaanticlinorium, is distinguished by a complex tectonic structure. According to its geomorphological, tectonic, lithological and stratigraphic properties, as well as oil and gas content, the depression is divided into northern, central, southwestern, southeastern Gobustan and Alat tectonic zones. Local uplifts developed within these zones are complicated by high-amplitude overthrusts and tectonic nappes. The study of the impact of compressional stresses (geodynamic factor) upon folding and faulting, mud volcanism and oil and gas content for the zones of the area under investigation stands out for its relevance. Decrease in intensity of compressional stresses from north to south along with increasing prospects of oil and gas content of the area is observed within the depression. The reason, as a rule, is the migration of fluids from high pressure zones towards low pressure zones. At the same time, along with the geodynamic factor, the reasons for the high prospects of the southern zone of the study area are the increase in the thickness of the Maikop, Chokrak and Productive Series ( $\mathrm{N}_{2}{ }^{1}$ b) sediments southwards and the spread of horizons of sandy reservoirs of sufficiently high thickness in the lithological composition.

The main aim of the study is to investigate the areal distribution properties of the main geodynamic factor - compressional stresses, which play an important role in formation and evolution of local uplifts and faults of various types complicating them, also of mud volcanoes, and in distribution of oil and gas fields within Shamakhy-Gobustan depression.

Subjects: structures and their lithofacial composition formed by Mesozoic deposits in the northern, Paleogene-Miocene deposits in the central and Pliocene deposits in the southern zones of the Shamakhy-Gobustan depression.

Methods. Using the morphology variation properties of folds developed in the Shamakhy-Gobustan depression, maps reflecting the magnitudes of the fault amplitudes along with isomorphic maps for the surfaces of Cretaceous, Maikop and Pliocene, northern, central and southern zones, as well as a diagram of the prospects for the oil and gas content of the area were built, intensity of distribution of compressional stresses in each zone were assessed.

Results. Compressional stress, as a geodynamic factor, played a significant role in formation of structural and tectonic layout of the sedimentary cover of the Shamakhy-Gobustan synclinorium. Local uplifts developed in all three zones of the Shamakhy-Gobustan depression were formed under the impact of both longitudinal and transverse bending mechanisms; widely developed mud volcanism, which is an indicator of oil and gas content, within the Shamakhy-Gobustan synclinorium and numerous natural oil and gas seeps make it possible to highly assess the prospects for oil and gas potential of autochthonous limbs of thrust and cover type structures; due to the direct impact of the distribution properties of the compressional stresses on fluid migration and formation of accumulations, depending on the geodynamic regime in the sedimentary cover, there is decrease in intensity of compressional stresses and increase in the oil and gas content of the area from north to south.

Key words:

Thickness, sand content, prospects, zone, structure, sediments, amplitude, age, cover, tectonic fault, overthrust, cleavage, oil, gas.

\section{REFERENCES}

1. Yusifov Kh.M. Neftegazonosnost $i$ neantiklinalnye lovushki paleogen-miosenovykh otlozheniy Shamakhy-Kobustana [Oil and gas potential and non-anticlinal traps of the Paleogene-Miocene deposits of Shamakhi-Gobustan]. Baku, Mars-Print Publ., 2016. $204 \mathrm{p}$.

2. Yusifov Kh.M., Rakhmanov R.R., Mamedov S.B., Efendiyev A.A. Geological foundations of prospecting for oil and gas fields in the Paleogene-Miocene sediments of East Azerbaijan. Geologist of Azerbaijan, 2006, no. 1, pp. 46-63. In Rus. 
3. Yusifov Kh.M., Rakhmanov R.R. Vybor napravleniya poiskovorazvedochnykh rabot $i$ utochnenie geologichekogo stroeniya i perspektivnosti mezokaynozoyskikh otlozheniy Yugo-Vostochnogo Gobustana-Zapadnogo Absherona: zaklyuchitelny otchet nauchno-issledovatelskoy raboty NIIGNCAR [Selection of the direction of prospecting and exploration work and clarification of the geological structure and prospects of Meso-Cenozoic deposits of South-Eastern Gobustan-Western Absheron: the final report of the research work of the Scientific Research Institute of the State Oil Company of the Republic of Azerbaijan]. Baku, 2008. 208 p.

4. Yusifov Kh.M., Efendiev A.A., Mamedov S.B. Perspektivnye napravleniya $\mathrm{i}$ analiz kompleksnogo geologo-geofizicheskogo izucheniya paleogen-mioesenovykh otlozheniy yugo-vostochnoy chasti Bolshogo Kavkaza [Prospective directions and analysis of a comprehensive geological and geophysical study of the PaleogeneMiocene deposits of the southeastern part of the Greater Caucasus] Scientific works Scientific Research Institute of the State Oil Company of the AR, 2006, no. 6, pp. 25-35.

5. Aliyev Ad.A. Gryazevoy vulkanizm Yuzhno-Kaspiyskogo neftegazonosnogo basseyna [Mud volcanism of the South Caspian oil and gas basin]. Geology and minerals of the World Ocean, 2006, no. 3, pp. 12-21. In Rus.

6. Narimanov N.R., Nasibova G.J., Mansurova S.I. Geodynamic regime of formation of the structural plan and oil and gas content of the Shemakha-Gobustan synclinorium. Geology, geophysics and development of oil and gas fields, 2017, no. 6, pp. 17-23. In Rus.

7. Aliyev Ad.A., Guliyev I.S., Dadashev F.N., Rakhmanov R.R. At las of the world mud volcanoes. Baku, Nafta-Press Publ., 2015. $205 \mathrm{p}$.

8. Guseynov B.B., Salmanov A.M., Magerramov B.I. Neftegazogeologicheskoe rayonirovanie territorii sushi Azerbaydzhana [Oil and gas geological zoning of the land territory of Azerbaijan]. Baku, Mars-Print Publ., 2019. 308 p.

9. Narimanov N.R. Geodinamicheskaya obstanovka obramleniya Yuzhno-Kaspiyskoy megavpadiny [Geodynamic setting of the framing of the South Caspian megadepression]. Geologist of Azerbaijan, 2005, no. 10, pp. 26-32.

10. Narimanov N.R. Vliyanie geodinamicheskikh protsessov na neftegazoobrazovanie v yuzhno-Kaspiyskoy vpadine [Influence of geodynamic processes on oil and gas formation in the South Caspian depression]. Azerbaijan Oil Industry, 2008, no. 8, pp. 13-18.
11. Kagramanov K.N., Ganiev N.M., Mukhtarova K.Z., Babaeva M.T. Simulating generation, accumulation and hydrocarbon migration ways in South Caspian Depression. Geology, geophysics and development of oil and gas fields, 2018, no. 6, pp. 37-45. In Rus.

12. Narimanov N.R., Gahramanov G., Babaev M.S., Shpirko S.G., Nasibova G.J., Mukhtarova K.Z. Prognosis of Baku archipelago hydrocarbon potential by types of mud volcanoes. Bulletin of the T. Shevchenko National University of Kyiv, Geology, 2019, no. 4 (87), pp. 55-62. In Rus.

13. Narimanov N.R., Babaev N.A., Gahramanov G., Javad-Zadeh Z. Cenozoic stag of development of local structures of the Lower Kura Depression and Baku Archipelago related to their oil and gas perspectivity. Geological Journal, 2018, 2 July, no. 10, pp. 337-341.

14. Alizadeh A.A., Guliyev I.S., Kadirov F.A., Epelbaum L.V. Geosciences of Azerbaijan. Economic Geoligy and Applied Geophysics, Springer International Publishing, 2017, vol. I, no. 10, pp. 340-351.

15. Mukhtarova K.Z., Nasibova G.J., Ahmadov M.G. The role of South-Eastern Gobustan and Absheron depressions clays with rheologically active properties in formation of structures and mud volcanism. American Association Educational Researcher, Washington, 2016 December, no. 9, pp. 673-678.

16. Yusifov M., Rabinowitz P. Classification of mud volcanoes in the South Caspian Basin, offshore Azerbaijan. Marine and Petroleum Geology, 2014, no. 21 (8), pp. 965-975.

17. Buniat-zade Z.A. Gas and oil volcanism: genesis and classification Proc. III International Conference of Azerbaijan Society of Oil Geologists. Baku, 1995. pp. 5-6.

18. Kerimov A.A., Guseynov G.M., Narimanov N.R. Geodynamical aspects of manifestations of diapirism and mud volcanism. Proc. III International Conference of Azerbaijan Society of Oil Geologists. Baku, 1995. pp. 4-5.

19. Bonini M., Tassi F., Feyzullayev A., Aliyev C. Deep gases discharged from mud volcanoes of Azerbaijan: New geochemical evidence. Marine and Petroleum Geology, 2013, no. 43, pp. 450-463.

20. Etiope G., Feyzullayev A., Baciu C., Milkov A. Methane emission from mud volcanoes in Eastern Azerbaijan. Geology, 2004, no. 32 (6), pp. $465-468$.

21. Roberts K., Stewart S., Davies R. Sector collapse of mud volcanoes. Journal of the Geological Society, 2011, no. 168 (1), pp. 49-60.

Received: 13 January 2021.

\section{Information about the authors}

Gultar J. Nasibova, Cand. Sc., associate professor, Azerbaijan State Oil and Industry University.

Khuraman Z. Mukhtarova, Cand. Sc., associate professor, Azerbaijan State Oil and Industry University. 